\title{
Integration of local wisdom coastal communities in early childhood education learning
}

\author{
Jamiludin, Halu Oleo University, Indonesia, jamiluddin@uho.ac.id, ORCHID: 0000-0002-5549-2554 \\ Sitti Rahmaniar Abubakar, Halu Oleo University, Indonesia, sittirahmaniar_fkip@uho.ac.id, ORCHID: \\ 0000-0002-6792-4262 \\ Darnawati, Halu Oleo University, Indonesia, darnawati@uho.ac.id, ORCHID: 0000-0002-7144-363X \\ Salim,_Halu Oleo University, Indonesia, salim@uho.ac.id, ORCHID: 0000-0002-9665-6324 \\ Waode Ade Sarasmita Uke $\_$Halu Oleo University, Indonesia, wd.ade_sarasmitauke@uho.ac.id, ORCHID: \\ 0000-0002-9375-034X
}

\begin{abstract}
The purpose of this study is to examine the integration of local wisdom coastal communities into early childhood education learning in the Buton, Indonesia. This research uses a mixed-method approach, i.e. combining qualitative and quantitative methods simultaneously. The results of this study indicate that the institution of early childhood education at Regency Buton already implement well the potential of local wisdom coastal communities into the learning of early childhood education. This is contained in the payload of the curriculum learning in aspects of child development (religious and moral values, physical development, cognitive, socio-emotional, language and art); aspects of the themes of learning, learning media aspects, aspects of the approach to learning and behavioral aspects of conditioning.

Keywords: Local Wisdom, Learning, Coastal Communities, Early Childhood Education.

Received: 20.11.2020 Accepted: 11.12.2020 Published: 08.01.2021
\end{abstract}

\section{INTRODUCTION}

Recognition of children is important because every child is unique (Pearsons \& Sardo, 2006). As a professional worker, the teacher places his/her position as a companion, mentor, and facilitator for children (Puckett \& Diffily, 2003). Teachers as educators must also transform in learning that adapts to the characteristics of the socio-cultural background of the community and cognitive characteristics of students as one of the strategic means for instilling the attitudes, knowledge, and skills used in the future.

Schools are the main environment for the child's development process, and play a role in creating activities for the welfare of children (Ben-Arieh, McDonnell, \& Schwartz, 2009). In this regard, the essential role of education is a key factor in socio-economic growth. Education has to be a strategic platform in order to develop all the potential of children so that all development can be achieved. (Khan, 2014). Schools can increase their competitiveness towards innovation and change in their management and all learning resources must be managed properly. Good management causes the activities of an institution to be better organized, monitored and controlled, therefore the expected goals can be achieved (Milena, 2013).

The potential local wisdom can provide positive values at schools and communities to achieve the nation's mental revolution. The degradation of the nation's morals and the diminishing value of customs reflected in every habit of the citizens of Indonesia are due to the degradation of local wisdom value. For this reason, there is a need for learning content that comes from local wisdom that grows in the community as a finding to support the development of education, especially early childhood education. The current early childhood education has experienced a paradigm shift (Santrock, 2006). These changes need to get serious attention to form a qualified child at an early age. In early childhood years, the main task for education and the development of psychologists is the assessment of children with developmental delays, and cognitive function is an important part of the comprehensive assessments (Kamppi \& Gilmore, 2010)

Early age is a golden age that only occurs once during a human's lifetime. At this moment, the process of growth and development in various aspects is going through a rapid period of development of human life. (Berk, 1992). Therefore, a serious, systematic and sustainable effort is needed to generate and strengthen children's potential, awareness, and beliefs from an early age. Osake (2009) indicates that children who have completed preschool education perform higher than students who do not undergo pre-school education on aspects of cognitive, psychomotor, and social skills. 
One effort that can be applied in the context of developing children's potential is learning the local wisdom. Local wisdom is a nation's identity or cultural character that enables the nation to incorporate, even develop, cultures from outside / other nations into its own character and skill (Wibowo, 2015). Local wisdom can be viewed as a vision of life and experience and as a tangible strategy of local community events to meet their needs (Alfian, 2013). Local wisdom is a link in the form of current culture, so that it is focused on life (Ratna, 2011).

Local wisdom is part of the knowledge of the local culture that is formed through the learning process by means of observation (Vorgie, Horsley, \& Jhonston, 2001). Local knowledge is local knowledge or indigenous knowledge, namely knowledge that has been tested and acquired by local communities or community in the local context (Cheng, 2002). Local knowledge or indigenous knowledge, over time, is not stagnant but dynamic and evolves. Indigenous awareness is the knowledge of people that has evolved and is gradually evolving in many societies over time. This is focused on centuries-old practice, adapted to the local culture and climate, complex and evolving (Mathias, 1996). In society, sources of local wisdom may be in the form of culture (values, norms, ethics, beliefs, practices, customary laws, and special rules) (Haryanto, 2014). In the form of language, both oral and written, local wisdom can also be (Ratna, 2011: 95). Oral can be in the form of folklore according to Igba, Nwachinemerem, \& Loretta (2016), folklore is used to instill modesty, moral values to children to adapt and respect their parents.

The potential of coastal communities Buton, Indonesia which has a natural fortress settlements majority is at the coast with sufficient natural resources both on land and at sea so that the potential benefit to the survival of local communities. The sea area of the coastal community of Buton Regency, Indonesia is also a maritime axis route. Judging from people's livelihoods, the average activity is as fishermen. Likewise with the culture that has its coastal communities in Buton Regency, Indonesia, which is very diverse due to the existence of many ethnic groups that grow in the community. The diversity of cultures from various ethnic groups into local communities is rich in cultural values and norms that are happy to grow and if not accommodated properly it will backfire for the community. The potential of this local wisdom needs to be integrated into Early Childhood Education learning so that from early age children will begin to recognize the potential of local wisdom in their area, therefore in the future children will be able to preserve, manage, and transform the superiority of their regions. The introduction of potential local wisdom from an early age is carried out considering the development of children's understanding of the social world is seen to be increasing. Children build social skills as they build friendships for the first time and have special relationships characterized by words and general interests in others. Berk (2012) explains that preschoolers quickly become social beings.

The potential local wisdom of the community will be a learning material and a pleasant learning environment for teachers and students, which allows teachers and students to actively participate based on the local wisdom they already know, hence the process and understanding of material internalized along with the learning outcomes can be obtained optimally. Students feel happy and are recognized for their existence and differences because the rich knowledge and cultural experience they have can be recognized in the learning process. Mannan, Sopyan, \& Sunarno (2015) also suggested the value of local wisdom incorporated into learning, arguing that the development of a learning tool that is integrated with regional potential is expected to grow each region's potential and boost students' creativity and character.

Learning that continues to prioritize the potential of local wisdom will be able to maintain and preserve the superiority of a regional product and along with the development of modern times. The values of local wisdom can shape a child's character to be good. According to Almerico (2014), children can learn about a good character is through high-quality learning literature. Therefore, the existence of Early Childhood Education learning content that contains the local wisdom of coastal communities can be good literature to maximize children's understanding and introducing local wisdom in their area and can form good character in children.

The focus of this research is: to analyze the implementation of the local wisdom coastal community the integrated learning in early childhood education in the Regency of Buton, Indonesia, and to describe the local wisdom coastal communities that are integrated into the learning of early childhood education in Regency of Buton, Indonesia.

\section{METHODS}

\section{Research Design}

The approach in this research method used a mixed method. Creswell (2014) revealed that a mixed method is a research approach by combining qualitative research with quantitative research. The strategy of the mixed method used in this study is a sequential explanatory strategy with the stages of which: (a) 
the first stage of collecting and analyzing quantitative data to answer the research focus on the implementation of local wisdom coastal communities in early childhood education learning in Buton, Indonesia, (2) the second stage, namely collecting and analyzing qualitative data to answer the research focus on the description of local wisdom coastal communities integrated into early childhood education in the Regency of Buton, Indonesia

\section{Sample of Research}

This research was conducted on early childhood education institutions located in the coastal communities in Regency of Buton, Indonesia. The selection of early childhood education institutions is based on its location on the coast and still has strong local wisdom values. Early childhood education institution that became the object of this study amounted to 6 schools those were kindergarten at Wabula, Bajo Bahari, Holimombo, Banabungi, Matanauwe, and Kumbewaha village. Furthermore, from each kindergarten, there were 2 teachers and 1 principal, so that the number of respondents was 18 people.

\section{Data Collection Technique}

The collection of data in this study used two instruments such as questionnaires, observation, and interviews. The questionnaire was used to collect data through forms that contain questions written in writing to someone or a group of people for answers or responses. The observation was used to collect data by conducting direct observation and systematic recording of objects to be researched. The interview was conducted to all respondents directly to get information regarding the type of local wisdom integrated into the context of early childhood education learning.

\section{Data Analysis}

The analysis of the data used in this study includes two stages, namely the analysis of qualitative data analysis and quantitative data. For quantitative data, research results are presented with statistical analysis in the form of the mean, standard deviation, categorization, and one-way ANOVA test. Results of the questionnaire respondents answered related to the implementation of local wisdom coastal communities that are integrated into the early childhood education learning created the categorization presented in table 1 below.

Table 1. The categorization of implementation of local wisdom coastal communities be integrated into learning early childhood education

\begin{tabular}{|l|l|}
\hline The average interval & Criteria \\
\hline $3,25-4,00$ & Very Good \\
\hline $2,50-3,25$ & Good \\
\hline $1,75-2,50$ & Less Good \\
\hline $1-1,75$ & Not Good \\
\hline
\end{tabular}

The use of the one way ANOVA test aims to analyze the difference in the implementation of local wisdom coastal communities that are integrated into the learning of early childhood education at the respective institutions. Data processing with the SPSS program with decision making that if the value is sig. smaller than $\alpha=0,05$ then there is a difference in the implementation of local wisdom coastal communities that are integrated into the learning of early childhood education at each institution.

As for the qualitative data through several stages, namely (1) editing process: i.e. researching back the record or information obtained from the data in the field to meet the information or records are already pretty well or not; (2) classifying that is read back and examines in depth the whole data obtained from the interviews is in compliance with the formulation of the problem; (3) verification, namely data obtained from the process of editing and classifying in crossed back in for validity met; (4) analyzing process i.e. the simplification of data into a form that is easier to read and interpreted, concluding that is the result of a process of taking the conclusion of the research process generates an answer be a generalization.

\section{RESULTS}

Research respondents were first given a questionnaire aimed at finding out the implementation of the wisdom of the coastal communities of Buton Regency which was integrated into early childhood learning. The measurement results contain 10 aspects of criteria, namely religious and moral values, physical- 
motor, cognitive, socio-emotional, language, art, the theme of learning, learning approach, media, and behavioral conditioning.

The results of the quantitative data analysis of the respondents' questionnaire answers are presented in Table 2 below.

Table 2. The results of the analysis applicability implementation local wisdom coastal communities be integrated into learning early childhood education

\begin{tabular}{|l|l|l|l|l|l|}
\hline \multirow{2}{*}{$\begin{array}{l}\text { Implementation of local wisdom } \\
\text { coastal communities }\end{array}$} & \multicolumn{2}{l|}{ The size of the } & \multicolumn{2}{l|}{ Statistical analyst } \\
\cline { 3 - 7 } & Mean & $\begin{array}{l}\text { Standard } \\
\text { devices }\end{array}$ & Categorization & F & Sig. \\
\hline Aspects of religious and Moral Values & 3,36 & 0,71 & Very Good & 1,280 & 0,307 \\
\hline Aspects of Physical-Motor Child & 3,43 & 0,63 & Very Good & 0,364 & 0,701 \\
\hline Aspects of Cognitive Child & 3,38 & 0,67 & Very Good & 1,721 & 0,212 \\
\hline Aspects of Socio-Emotional Child & 2,89 & 0,64 & Good & 1,204 & 0,327 \\
\hline Aspects of Child Language & 3,47 & 0,74 & Very Good & 0,061 & 0,941 \\
\hline Aspects of Child Art & 3,31 & 0,61 & Very Good & 0,357 & 0,705 \\
\hline The Theme Of Learning & 3,33 & 0,72 & Very Good & 0,127 & 0,882 \\
\hline Learning Approach & 2,82 & 0,84 & Good & 0,299 & 0,746 \\
\hline Learning Media & 3,51 & 0,62 & Very Good & 0,267 & 0,769 \\
\hline Behavioral Conditioning & 3,32 & 0,73 & Very Good & 0,144 & 0,867 \\
\hline Average & 3,28 & Very Good & & \\
\hline
\end{tabular}

The results in Table 2 showed that the average implementation of local wisdom in the coastal communities of Buton Regency was in the very good category. As for the results of the F-Test on all aspects showed that all aspects had sig. greater than $\alpha=0.05$. The results of this statistical analysis indicated that all Kindergartens who were respondents had the same perception of the implementation of early childhood education by instilling local wisdom in the coastal communities of the Buton Regency or it could be said that the respondents' answers in each Kindergarten did not have different views towards the local wisdom of coastal communities.

The results of observations on six kindergartens in the coastal communities of Buton Regency on the values of local wisdom implemented in early childhood learning that includes aspects of traditional clothing, traditional dances, traditional musical instruments, traditional games, traditional food, sea life, and philosophy of life. The results of these observations appear in the following Table 3.

Table 3. Results of observation of the values of local wisdom of coastal communities implemented in early childhood learning

\begin{tabular}{|l|l|}
\hline Type & Result of Observation \\
\hline Traditional Clothing & $\begin{array}{l}\text { Leja fabrics, namely buton weaving, clothing worn by traditional leaders (parabela, } \\
\text { moji, waci, pandesuka) }\end{array}$ \\
\hline Traditional Dances & mangaru dance, linda dance, and bosu dance. \\
\hline $\begin{array}{l}\text { Traditional Musical } \\
\text { Instruments }\end{array}$ & ghanda (drum), mbololo (gong), gambusu (cymbals). \\
\hline Traditional Game & game kesede-sede, and ase \\
\hline Traditional Food & lapa-lapa, cucur, wadi, onde-onde, tuli-tuli, baruasa \\
\hline Sea Life & shellfish, gravel, sand, rompong, reef fish, beach recreation \\
\hline Philosophy Of Life & $\begin{array}{l}\text { Katoono mia toaru (cooperative society), Poma-maasiaka (love one another), Tadhe } \\
\text { atadhea hora ahoraa (same high standing in the same sitting low), Pohamba-hamba } \\
\text { (mutual aid), Popia-piara (keeping each other), Pomali ( the ban), Pomae-maeka } \\
\text { (mutual love), Poganta-ganta (share) }\end{array}$ \\
\hline
\end{tabular}

Research respondents were also interviewed to describe the components of early childhood learning that included aspects of local wisdom in the coastal communities of Buton Regency. The following excerpts from interviews with several respondents.

... We have incorporated the local wisdom of coastal communities in early childhood learning for all aspects of child development ranging from religion and morals, physical motor, cognitive, socialemotional, language, and art. 
The respondent's quote describes that institutions in kindergartens in the coastal community areas of Buton Regency have learned the meaning of local wisdom values to be integrated in early childhood learning. In order for early childhood learning to be achieved the teacher needs to design the learning theme as well as possible. The theme is an extension of insight to support the maturity of early childhood development.

.... The emergence of learning themes is the theme of animals and the life of the sub-themes of living animals in the water, themes of vehicles for vehicle sub-themes at sea, cultural themes of traditional clothing, traditional foods, traditional dances, traditional games.

From the respondents' answers, it was revealed that there were themes adapted by the teachers in designing learning according to the potential of local wisdom possessed by coastal communities. The theme designed is also not in conflict with the guidelines for the compilation of learning themes issued by the Ministry of Education and Culture of the Republic of Indonesia.

... Media used in early childhood education learning constructed and shaped local wisdom-based coastal communities with the goal of keeping the child easily remembering and understanding the local wisdom of his territory. Media images of pictures object to local wisdom coastal communities.

The media used by the teacher is still simple, but always elevates the potential of the local wisdom of coastal communities. The use of media by the teacher starts from the container, its form and content always take from local wisdom.

...Teachers of early childhood education have done local wisdom-based learning coastal communities (etnopedagogy masir) this approach is the integration of learning by placing local wisdom as a source and material to learn effective, easy, cheap, close to children and contain a good value for the formation of character.

The answer from the respondent's quote shows that the teacher has used a new approach in learning that is adapted to the potential of the local wisdom of coastal communities namely called Etnopedagogy-Masir. Furthermore, related to the habituation activities carried out by the teacher every day at the kindergarten institutions in the coastal area of Buton Regency, can be described from the following respondents' answers.

... On conditioning, the child looks at traditional songs included on a regular song at the beginning and at the end of learning. Conditioning can also be done on the philosophical life introduced with coastal communities in every activity and loads of learning early childhood education.

The two most domain aspects related to the habits applied by teachers in the activities of children aged din namely the existence of traditional songs and the philosophy of life of coastal communities. These two aspects are always present on a daily basis so that they become entrenched in children who take part in learning activities.

\section{DISCUSSION AND CONCLUSIONS}

The implementation of local wisdom has been integrated into early childhood learning in the coastal community area of Buton Regency. This success is inseparable from the role of local culture and customs that have maintained their existence and are still considered sacred to be used as guidelines in society today. The results of this study indicate the role of the teacher is quite central to presenting local wisdom in learning. Children from an early age need to be introduced to the potential and values of their local wisdom so that they will become human beings who can maintain, manage, and preserve local wisdom so that they can become independent and competitive communities. The result of the statistical analysis shows that on average the implementation of local wisdom coastal communities that are integrated into the learning of early childhood education to be implemented very well. Early childhood education institution that existed in the coastal region of the Regency Buton is considered quite successfully integrating the potential of their local wisdom in learning early childhood education. Test ANAVA also shows there is no difference in the implementation of local wisdom coastal communities that are integrated into the learning of early childhood education at three of the coastal area. This means that the three regions jointly implementing early childhood education learning by integrating local wisdom coastal communities

The development of early childhood education learning based on local wisdom in coastal communities in early childhood education learning that looks at the potential of the area that can be utilized by teachers in learning. Currently, almost all early childhood education institutions, especially Buton Regency, Indonesia have maximally utilized the potential of their local wisdom as an effective learning resource in learning to improve the achievement of child development. Therefore, the development of this learning becomes a reference for teachers and early childhood education institutions in developing learning. There is a need for local wisdom-based learning of coastal communities, therefore 
children feel close and comfortable with the environment which is an activity of daily life. Jung, Sun, \& Yeon (2014) suggested the main aspect that children should have when entering primary school is the ability to feel safe and comfortable socially and emotionally.

On every aspect of child development appears every child activity that reflects the implementation of local wisdom coastal communities in early childhood education learning. Developmental aspects of religious values and morals, teachers generally make an effort to keep child care conditioning of God's creation in the form of local wisdom coastal communities. Children's activity on the aspects of physical development motor that is (a) mimics a regular range of motion eg: gymnastics and traditional dance, (b) to draw local wisdom coastal communities, (c) stick to eating traditional food.

Children's activity on the cognitive aspects, namely (a) apply knowledge or experience in the context of the new (the wisdom local coastal communities), (b) classify the objects of local wisdom coastal communities based on functions, (c) know the distinction based on the size of the corresponding objects in the coastal community of local wisdom: "more than", "less than", "most ', (d) classify the objects of local wisdom coastal communities based on colors, shapes, and sizes (three variations), (e) classify the objects of local wisdom coastal communities are more into the same group or same-sex groups, or groups of twos are more than two variations and four letters) (f) sort the objects of local wisdom coastal communities by size from smallest to largest or vice versa, (g) mentions the symbol number one-ten using the objects of local wisdom coastal communities

Children's activity on the aspects of the language that is to know the sound of the first letter name objects of local wisdom coastal communities, mention the group sound/image that has the same initial letter of the local coastal community wisdom, understanding the relationship between sounds and letters from of local wisdom coastal communities. Children's activities on the socio-emotional look at the traditional game played by children. Children's activities at the art look at aspects of traditional dance, traditional tools, crafts, traditional clothing, traditional songs

Early childhood education learning media developed by utilizing the potential of the local wisdom of coastal communities are used in the learning process both outdoor and indoor. Learning media used in the learning process with children indoor means that the learning media is brought into the room. While the outdoor learning process means that the learning media is obtained during learning in the area. Assessment and evaluation of the flow of the implementation of media programs and early childhood education teaching materials are also outputs from the results of the learning process. In the early childhood education process, learning that must be achieved, for instance: the development of religious and moral values; language development; physical development; social-emotional development; cognitive development. The development of coastal wisdom-based of early childhood education learning media needs to be carried out with the aim, for instance: to maximize early childhood education institutions to make the diversity of the potential local wisdom as a learning medium, to motivate teachers to develop learning media using the potential of the local wisdom coastal communities, and to accelerate achievement of child development age of 5-6 years.

The learning approach that is used by teachers of early childhood education at coastal communities namely learning-based coastal communities local wisdom or can be called etnopedagogimasir. Etnopedagogi-masir approach planning requires extensive information and in-depth associated potential local wisdom that needs to be mastered and understood by teachers of early childhood education to be able to integrate it in the learning that will be compiled. Local wisdom coastal communities that will be integrated needs to be excavated and understood so that it can adjust to the needs of students learning. An early childhood learning approach that integrates the wisdom of local coastal communities is an integration of learning by placing local wisdom as learning resources.

The teacher in determining the theme must pay attention to the potential of local wisdom in his/her area. In coastal communities, a theme becomes urgent because the theme of learning functions as a container containing material and learning approaches to develop children's potential. The chosen theme blends with the development of children's activities, learning materials, and competencies in one unit which is more meaningful to enrich children's insights and vocabulary. Hence, their learning outcomes become better. Learning materials based on local wisdom according to Bauto (2013), there are many values of local wisdom in each field in developing teaching materials. Therefore, they can improve students' knowledge, attitudes, and skills. Learning materials that contain local wisdom values can enhance the acquisition of positive values for students

On conditioning the child activity, the teacher begins to introduce the philosophy of living coastal communities a Buton Regency can serve as the value of the character formation of identity and behavior of early childhood. The life philosophy of value are: Katoono mia toaru (cooperative society), Pomaamaasiaka (love one another), Tadhe atadhea hora ahoraa (same high standing in the same sitting low), 
Pohamba-hamba (mutual aid), Popia-piara (keeping each other), Pomali (Prohibition), Pomae-maeka (mutual love), Poganta-ganta (mutual sharing).

\section{CONCLUSIONS}

The conclusion of this study is that the local wisdom of coastal communities needs to be integrated into the early childhood education learning process, therefore from an early age, the child has begun to touch the lives of his daily environment and knows his environment about the local wisdom possessed by his area. The local wisdom of the coastal communities of Buton Regency can be tangible such as traditional clothing, traditional dances, traditional musical instruments, traditional games, traditional food, and marine biota. Components of local wisdom that can be integrated into early childhood education learning are contained in: aspects of child development (religious and moral values, physical, cognitive, language, socio-emotional and artistic development); aspects of learning themes, aspects of learning media, aspects of learning approaches and aspects of habituation behavior.

\section{REFERENCES}

Alfian, M. (2013). Potensi Kearifan Lokal Dalam Pembentukan Jati Diri dan Karakter Bangsa. Paper presented at the Prosiding The 5th International Conference on Indonesia Studies:Ethnicity and Globalization.

Almerico, G. (2014). Building Character through Literacy with Children's Literature. Research in Higher Education Journal, 26(1), 1-13.

Bauto, L. M. (2013). Socio-Cultural Values as Community Local Wisdom Katoba Muna in The Development Of Learning Materials Social Studies and History. International Journal Education, 14(2), 195-218.

Ben-Arieh, A., McDonnell, J., \& Schwartz, S. A. (2009). Safety and home-school relations as indicators of children wellbeing: whose perspective count? Social Indic Res, 90, 339-349.

Berk, L. E. (Writer) (1992). Children's Private Speech: An Overview Of Theory And The Status Of Research, In R.M. Diaz \& L.E. Berk (Eds), Private Speech: From Social Interaction To Self Regulation.UK: Lawrance Erlbaum Associates.

Berk, L. E. (Ed.). (2012). Development through the lifespan (Terjemahan) Daryatno. Yogyakarta: Pustaka Pelajar.

Cheng, Y. C. (2002). Fostering Local Knowledge and Wisdom in Globalized Education: Multiple Theories. Paper presented at The 8th International Conference on "Globalization and Localization Enmeshed: Searching for a Balance in Education, Thailand: Bangkok.

Creswell, J. W. (2013). Educational Research: Planning, conducting, and evaluating quantitative and qualitatif research. Fourth Edition. Pearson International Edition. New Jersey: Pearson Education Inc.

Haryanto, J. T. (2014). Kearifan Lokal Pendukung Kerukunan Beragama pada Komunitas Tengger Malang di Jawa Timur. Jurnal Analisa, 21(2), 201-213.

Igba, D. I., Nwachinemerem, C., \& Loretta, I. (2016). Use of Folklores in Inculcating Viable Values in Youths within Families Inohaukwu Local Government Area, Ebonyi State, Nigeria. The International Journal of Humanities \& Social Studies, 4(5).

Jung, J., Lim, Sun, H., Ahn, \& Yeon, H., Kim. (2014). Quality of Childcare and School Readiness of Children in Poverty: A South Korean Study. Journal of Department of Child \& Family Studies Kyung Hee University, 5(1).

Kamppi, D., \& Gilmore, L. (2010). Assessing cognitive development in early childhood: a comparison of the BayleyIII and the StanfordBinet fifth edition. Journal Australian Educational and Developmental Psychologist, 2(4).

Khan, S. (2014). The Supervisory Role of The Headmaster at The Higher Secondary Level: A Teacher's Perception. Public Policy and Administration Research IISTE, 4(9), 51-54.

Mannan, M., N, Sopyan, A., \& Sunarno. (2015). Pengembangan Perangkat Pembelajaran Berbasis Kearifan Lokal Untuk Mengembangkan Karakter Positif Siswa SD. Jurnal Inovasi Dan Pembelajaran Fisika, 2(2), 141-146.

Mathias, E. (1996). Recording and Using Indigenous Knowledge: A Manual. International Institute of Rural Reconstruction.

Milena, J. (2013). Potential Future Managers and Their Opinion on the Issue of Diversity, Inclusion and Their Possible Use in Management. Journal of Competitiveness, 5(2), 37-50. 
Osakwe, R. N. (2009). The Effect Of Early Childhood Education Experience On The Academic Performances Of Primary School Children. Studi Home comm Sci.

Pearsons, H., \& Sardo, B., (2006). Educational psychology. Boston: Wadsworth Thomson Learning. Inc

Puckett, M., B, \& Diffily, D. (2003). Teaching Young Children: An Introduction to the Early Childhood Profession, Second Edition. Canada: Thomson Learning, Inc.

Ratna, N., Kutha. (2011). Metodologi Penelitian: Kajian Budaya dan Ilmu Sosial Humaniora Pada Umumnya. Yogyakarta: Pustaka Pelajar.

Santrock, J. W. (2006). Life Span Development. Boston: McGraw-Hill Co.Inc.

Vorgie, V., Horsley, P., \& Jhonston, J. (2001). Facilitating Community-Based Conservation Initiatives: Science for Conservation. New Zealand: Departement of Conservation Wellington.

Wibowo, A. (2015). Pendidikan Karakter Berbasis Kearifan Lokal Di Sekolah. Yogyakarta: Pustaka pelajar. 